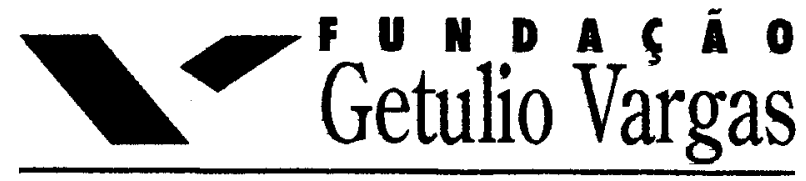

EPGE

Escola de Pós-Graduação em Economia

Seminários de Pesquisa Econômica II (I ${ }^{a}$ parte)

\section{"FLECTORAL INSTITUTIONS, \\ CLFAVAGE STRUCTURES, AND THE NUMBER OF PARTIFS"}

\section{OCTAVIO AMORIM NETO}

(Department of Political Science -

University of California)

LOCAL:

Fundação Getulio Vargas

Praia de Botafogo, $190-10^{\circ}$ andar

Auditorio

DATA:

$25 / 07 / 96\left(5^{\mathrm{a}}\right.$ feira $)$

HORÁRIO: 16:00h 


\title{
ELECTORAL INSTITUTIONS, CLEAVAGE STRUCTURES, AND THE NUMBER OF PARTIES*
}

\author{
by \\ Octavio Amorim Neto \\ and \\ Gary W. Cox \\ Department of Political Science \\ University of California, San Diego \\ La Jolla, CA 92093-0521
}

September 1995

* Amorim Neto's work was funded by the Brazilian Ministry of Education under grant number 2064/92-3. Cox's work was supported by the NSF under grant number SBR-9422874. We thank Matthew Shugart for his helpful comments. 


\section{Abstract: \\ Electoral Institutions, Cleavage Structures, and the Number of Parties}

Theory: A classic question in political science concerns what determines the number of parties that compete in a given polity. Broadly speaking, there are two approaches to answering this question, one that emphasizes the role of electoral laws in structuring coalitional incentives, another that emphasizes the importance of pre-existing social cleavages. In this paper, we view the number of parties as a product of the interaction between these two forces, following Powell (1982) and Ordeshook and Shvetsova (1994).

Hypotheses: The effective number of parties in a polity should be a multiplicative rather than an additive function of the permissiveness of the electoral system and the heterogeneity of the society.

Methods: Multiple regression on cross-sectional aggregate electoral statistics. Unlike previous studies, we (1) do not confine attention to developed democracies; (2) explicitly control for the influence of presidential elections, taking account of whether they are concurrent or nonconcurrent, and of the effective number of presidential candidates; and (3) also control for the presence and operation of upper tiers in legislative elections.

Results: The hypothesis is confirmed, both as regards the number of legislative and the number of presidential parties. 


\section{Electoral Institutions, Cleavage Structures, and the Number of Parties}

The study of political parties and party systems is one of the largest subfields of political science. Within this subfield, a classic question concerns what determines the number of parties that compete in a given polity. Broadly speaking, there are two approaches to answering this question, one that emphasizes the role of electoral laws in structuring coalitional incentives, another that emphasizes the importance of pre-existing social cleavages.

The first approach--found in the work of such scholars as Duverger (1954), Sartori (1968, 1976), Rae (1971), Lijphart (1990; 1994), Riker (1982), Taagepera and Shugart (1989), Palfrey (1989), Myerson and Weber (1993), and Cox (1994)--can be exemplified by what Riker has dubbed Duverger's Law: the proposition that "the simple-majority single-ballot system [i.e., simple plurality rule in single-member districts] favors the two-party system" (Duverger 1954, p. 217). The logic behind this proposition looks both to the incentives that face voters under the plurality voting system (they will avoid wasting their votes on hopeless third party candidacies) and to the incentives that consequently face elites (they will avoid wasting their time, money and effort in launching what the voters will perceive as hopeless candidacies, instead looking to form coalitions of sufficient size to win a plurality).

The second approach--associated with the work of such scholars as Grumm (1958), Eckstein (1963), Meisel (1963), Lipson (1964), Lipset and Rokkan (1967), Rose and Urwin (1970)--can be exemplified by Lipset and Rokkan's famous freezing hypothesis: the proposition that the European party systems stabilized or "froze" in the 1920s, and continued with the same basic socially-defined patterns of political competition (and sometimes the same parties competing) until at least the $1960 \mathrm{~s}$. The logic behind this proposition relies on an implicit notion of social equilibrium to account for the longevity of the party systems spawned in early twentieth-century European industrial democracies. 
The two approaches just sketched coexist uneasily. Some adherents of the sociological school question whether Duverger's generalizations serve "any useful function at all" (Jesse 1990, p. 62); argue that the institutionalists have got the direction of causality backwards; ${ }^{1}$ or argue that the institutionalists have simply focused on a relatively unimportant variable, at the expense of a relatively more important variable--the number and type of cleavages in society. ${ }^{2}$ Adherents of the institutionalist approach object to a belief that socially defined groups will always be able to organize in the political arena, because this ignores the problem of collective action (Olson 1965); or object to a belief that social groups will always organize as parties, because this assumes that "going it alone" is always a better strategy than forging coalitions; or argue that politicians can take socially defined groups and combine or recombine them in many ways for political purposes (Schattschneider 1960)--so that a given set of social cleavages does not imply a unique set of politically activated cleavages, and hence does not imply a unique party system. $^{3}$

Despite these differences, however, the two approaches are not mutually exclusive. To assert that social structure matters to the formation and competition of parties--which noone denies, when the point is stated in such a broad fashion--does not imply that electoral structures do not matter. To make this latter point, one has to adopt a rather extreme monocausalist perspective according to which the underlying cleavage structure of a society is so much more important than the details of electoral law tha ${ }^{4} t$ basically the same party system would arise regardless of the electoral system employed (cf. Cairns 1968, p. 78). Does anyone believe that the U.S. would remain a two-party system, even if it adopted the Israeli electoral system?

Similarly, to assert that electoral structure affects party competition in important and systematic ways does not imply that social structure is irrelevant. It might appear that this is exactly what Duverger's Law does imply--bipartism in any society merely upon application of single-member districts--but in fact that overstates Duverger's proposition and the institutionalist development of it, where there has been an increasing appreciation of the interaction effects between social and electoral structure. 
Duverger did take social structure more or less as a residual error, something that might perturb a party system away from its central tendency defined by electoral law. Later scholars, however, have considered the possibility that cleavage and electoral structures may interact. This has been the case in the string of papers that consider the importance of the geographic location of supporters of a given party (e.g., Sartori 1968; Rae 1971; Riker 1982; Kim and Ohn 1992) and also in a recent pair of works (Powell 1982; Ordeshook and Shvetsova 1994) that have included both sociological and institutional variables in regression analyses of cross-national variations in the number of parties.

This paper follows the latter set of works in that it investigates the role of both social cleavages and electoral laws in determining the number of parties. We put particular emphasis on testing Ordeshook and Shvetsova's main finding--that there is a significant interaction between social heterogeneity and electoral structure. In order to put this claim to a stringent test, we employ a substantially different dataset--one that includes about twice as many countries as have previous studies, including a large number of third-world democracies--and model the impact of both electoral structure and presidential elections differently than have previous studies.

The structure of the paper is as follows. Section 1 sketches a hypothetical series of stages by which social cleavages are reduced to party-defining cleavages, noting that some stages are sensitive to the particularities of social structure, some to the details of electoral structure, and some to both. The sketch outline suggests the inclusion of both social and electoral variables in statistical analyses of the number of parties and Section 1 also reviews the work of Powell (1982) and Ordeshook and Shvetsova (1994), noted above, that takes this approach. Section 2 explains how our data and methods differ from, and complement, previous efforts. Section 3 presents our results. Section 4 concludes. 


\section{Social Cleavages, Possible Parties, and Actual Parties}

The effective number of elective or legislative parties in a polity can be thought of as the end product of a series of decisions by various agents that serve to reduce a large number of social differences, or cleavages, to a smaller number of party-defining cleavages. ${ }^{5}$ There are three broad stages to consider in this process of reduction: the translation of social cleavages into partisan preferences; the translation of partisan preferences into votes; and the translation of votes into seats.

In most institutionalist models, the first stage is not explored: there is an exogenously given number of parties with clear demarcating features (e.g., the position they adopt along an ideological dimension), so that voters' preferences over parties are easily deducible. No party ever fails to get votes because it is too poor to advertise its position; no would-be party ever fails to materialize because it does not have the organizational substrate (e.g., labor unions, churches) needed to launch a mass party. In an expanded view, of course, the creation of parties and the advertisement of their positions would be key points at which a reduction of the number of political players occurs. The multiplicity of possible or imaginable parties is reduced to an actual number of launched parties even before the electorate produces an effective number of votegetting parties, and the electoral mechanism produces an effective number of seat-winning parties. $^{6}$

The reduction of launched parties to voted-for parties is the domain of strategic voting. Even if launched, a party still has to be perceived as viable in order to turn favorable preferences into votes. Whether it is so perceived depends on how many other parties are chasing after votes and on the details of electoral structure. In particular, Sartori's (1968) notion of the strength of an electoral system (where the strength in question is that of the incentives to coalesce that the electoral system produces) is useful here. The stronger the electoral system, the greater will be its efficiency in reducing an excessive number of known parties to a smaller effective number of 
voted-for parties. (Operational measures of the strength of an electoral system will be introduced below.)

Finally, the reduction of voted-for parties to seat-winning parties is typically a mechanical feature of the electoral system. The only substantial exceptions within individual electoral districts occur when votes are not pooled across all candidates from a given party, as in Taiwan or Colombia. In these systems, the distribution of a party's rote support across its candidates or lists materially affects its seat allocation (cf. Cox and Shugart N.d.).

Given this general picture of how parties arise and of how the level of vote or seat concentration is set, one would imagine that studies of the effective number of elective or legislative parties would investigate the impact of both social cleavages and electoral laws on party system fractionalization. However, among quantitative studies we are aware of only two that do this. The first of these, Powell (1982), looks only at legislative fractionalization while the second, Ordeshook and Shvetsova (1994), looks at both elective and legislative fractionalization.?

Powell's work focuses on a set of 84 elections held in 27 mostly European countries during the period 1965-1976. The dependent variable, legislative fractionalization, is measured by Rae's index (that is, $1-\sum s_{i}^{2}$, where $s_{\mathrm{i}}$ is the seat share of the ith party). The independent variables of primary interest are three measures of social heterogeneity--ethnic fractionalization as measured by Rae's index (that is, $1-\sum g_{i}^{2}$, where $\mathrm{g}_{\mathrm{i}}$ is the proportion of the population in ethnic group i); an index of agricultural minorities (coded 3,2 or 1 if the agricultural population comprises $20-49 \%, 50-80 \%$, or $5-19 \%$ of the total population); and an index of Catholic minorities (coded similarly to the agricultural index)--and two measures of electoral structure-the "strength" of the electoral system for legislative elections (coded 3 for single-member plurality elections, 2 for the Japanese, German and Irish systems, and 1 for proportional systems); and a dummy variable indicating whether or not the system is presidential ( 1 if yes, 0 if no). ${ }^{8}$ Regressing the independent variables just listed on the legislative fractionalization scores for each election. Powell (p. 101) finds that "fractionalization is encouraged above all 
by...nonmajoritarian electoral laws, but also by all of the heterogeneity measures, and discouraged by presidential executives."

Ordeshook and Shvetsova (1994) consider several different data sets: Lijphart's (1990) sample of 20 Western democracies from 1945-85 (representing 32 distinct electoral systems); an extension of this dataset covering elections in 23 Western democracies from 1945-90 (representing 52 distinct electoral systems); and a further extension that includes Continental elections in the period 1918-39. The dependent variables that Ordeshook and Shvetsova investigate are four: the effective number of elective parties (ENPV $=1 / \sum v_{i}^{2}$, where $v_{i}$ is party i's vote share); the effective number of legislative parties (ENPS $=1 / \sum s_{i}^{2}$, where $s_{i}$ is party i's seat share); the number of parties that receive at least $1 \%$ of the vote in two or more successive elections; and the number of parties that secure one or more seats in two or more successive elections. They measure social structure chiefly in terms of ethnicity, calculating the effective number of ethnic groups (ENETH $=1 / \sum g_{1}^{2}$, where $g_{i}$ is the proportion of the population in ethnic group i); and meaure electoral system properties by the average district magnitude and by Taagepera and Shugart's "effective magnitude" measure. They then use OLS regression to explain variations in their dependent variables (here we shall look just at ENPV), considering three basic specifications: (1) The institutionalist specification: ENPV as a function solely of the log of district magnitude, as in Taagepera and Shugart (1989); (2) The sociological specification: ENPV as a function solely of ethnic heterogeneity; and (3) The interactive specification: ENPV as a function of the product of ethnic heterogeneity and district magnitude. They find that the interactive model does best in explaining the data, summarizing their findings as follows:

...if the effective number of ethnic groups is large, political systems become especially sensitive to district magnitude. But if ethnic fractionalization is low, then only especially large average district magnitudes result in any 'wholesale' 
increase in formally organized parties. Finally, if district magnitude equals one, then the party system is relatively 'impervious' to ethnic and linguistic heterogeneity... (Ordeshook and Shvetsova 1994, p. 122).

Thus, whereas Powell (1982, p. 81) had success with an additive specification, Ordeshook and Shvetsova find an interactive model to be superior.

Why should an interactive model work well? One answer runs as follows. A polity will have many parties only if it both has many cleavages and has a permissive enough electoral system to allow political entrepreneurs to base separate parties on these cleavages. Or, to turn the formulation around, a polity can have few parties either because it has no need for many (few cleavages) or poor opportunities to create many (a strong electoral system). If these claims are true, they would rule out models in which the number of parties depends only on the cleavage structure, or only on the electoral system, or only on an additive combination of these two considerations. $^{9}$

Plausible though this formulation might be, it still leaves several questions unanswered. First, and most important, is the question of empirical evidence. Thus far we have one study in which an additive specification seems to work well (Powell) and one study in which an interactive specification proves superior (Ordeshook and Shvetsova). The latter study, moreover, is based largely on European evidence, and one might well ask what would happen if India (or other socially diverse third-world countries with strong electoral systems) were added. Since India appears to have lots of social cleavages and also to have lots of parties, would the addition of this (kind of) case to the analysis not bolster the importance of social heterogeneity and, perhaps, point more toward an additive rather than an interactive specification? Second, there is also the issue of what the form of the interaction between electoral and cleavage structure is. Perhaps the effective number of elective parties (ENPV) should equal the minimum of (1) the number of parties that the cleavage structure will support (loosely following Taagepera and Grofman 1985, we might say this number was $\mathrm{C}+1$, where $\mathrm{C}$ is the number of cleavages); and (2) 
the number of parties that the electoral system will support (following the "generalized Duverger's Law" of Taagepera and Shugart 1989. we might say this number was $2.5+$ $1.25 \log _{10} \mathrm{M}$. where $\mathrm{M}$ is the district magnitude). That is, perhaps the equation should be something like ENPV $=\mathrm{MNN}\left[2.5+1.25 \log _{10} \mathrm{M}, \mathrm{C}+1\right]$. Or, perhaps the form of the interaction is as Ordeshook and Shvetsova specify it, a simple product of factors reflecting electoral strength and number of cleavages. In the next two sections, we investigate both these questions, especially the first.

\section{Data and Methods}

In considering the interaction between social heterogeneity and electoral permissiveness, our analytical strategy is to look at different data than did Ordeshook and Shvetsova (1994), using different operational measures of key variables. The notion is that, if their basic finding of a significant interaction is robust to these changes, then we can have more confidence in it. The most important differences between our analysis and Ordeshook and Shvetsova's are as follows: we include a larger number of countries, including many third-world democracies; we measure the strength of an electoral system by employing separate measures of lower-tier district magnitude and upper-tier characteristics, rather than combining these two factors (in an "effective magnitude") or ignoring upper tiers (by taking a simple average of the district magnitudes); and we include variables tapping the influence of presidential elections (if any) in the system. Let us consider each point in turn. ${ }^{10}$

Case selection: We have taken as a case every polity with an election in the $1980 \mathrm{~s}$ (defined as 1980-1990 inclusive) that qualifies as 'free' by Freedom House's score on political rights (either a 1 or a 2); if a polity has multiple such elections in the 1980s, we have taken the

one closest to 1985." These criteria of selection mean that we have a substantially more diverse sample than do Ordeshook and Shvetsova (or Powell before them), one that includes India, Venezuela. Mauritius and many other third-world countries (see the appendix). The total number 
of countries included is 54 . As there is only one observation per country, our sample can also be described as having observations on 54 electoral systems.

Measuring electoral structure. We differ from Ordeshook and Shvetsova and most of the previous literature in that we do not use average magnitude or Taagepera and Shugart's 'effective magnitude' as our main indicator of the strength of an electoral system. Instead, we use two variables, one to describe the magnitude of the lower-tier districts, one to describe the impact of the upper tier.

The lower tier variable that we use is based on the magnitude of the median legislator's district. An example may help to clarify why we use this variable rather than simply the average district magnitude. Suppose an electoral system has just two districts, one returning a single member and one returning 100 members. The average district magnitude in this system is $(100+1) / 2=50.5$. But this process of averaging, in which each district counts equally, does not correspond to the usual way in which the effective number of parties is calculated. To see this, suppose that there are 100 voters in the 1-seat district, who split equally between two parties, while there are 10,000 voters in the 100-seat district, who split equally between ten parties. In this case, the effective number of parties in the 1-seat district, the 100-seat district, and the nationa as a whole are respectively 2,10 , and almost 10 . The national effective number of parties is much closer to the effective number of parties in the large district because the votes from both districts are simply added to arrive at the national vote totals, and there are 100 times more voters in the large district than in the small. The national effective number of parties, in other words, is a weighted average of the district figures, in which larger districts get more weight. Accordingly, it seems natural to use a similarly weighted measure of the central tendency in district magnitudes. We choose to weight each district by the number of legislators from that district (which, if there is no malapportionment in the system, and turnout is equal across districts, will correspond to the weights used in calculating the national effective number of parties). We also have chosen to use medians rather than means. In the example at hand, this yields a figure of 100: there are 101 legislators, of whom 100 are elected from a district of 
magnitude 100; the magnitude of the median legislator's district is thus 100. As it turns out, using the average of the legislators ${ }^{\circ}$ district magnitudes. rather than the median, has virtually no impact on the results that follow. Finally, we follow Taagepera and Shugart (1989) and take the logarithm of the median legislator's district's magnitude, to produce a variable we denote LML.

The upper tier variable that we use, denoted UPPER, equals the percentage of all assembly seats allocated in the upper tier(s) of the polity. It ranges from zero for polities without upper tiers to a maximum of $50 \%$ for Germany. The idea here is that instead of attempting to deduce how the existence of an upper tier affects the "effective magnitude" of a system, we simply let the upper tiers speak for themselves. Because all but one of the upper tiers in our sample are compensatory--designed specifically to increase the proportionality of the overall result--we can avoid some of the complexities of Taagepera and Shugart's "effective magnitude," which attempts to put the effects of compensatory and additional seats on a common metric (Taagepera and Shugart 1989, ch. 12).12

Presidentialism. Several previous studies--e.g., Powell (1982), Lijphart (1994), Jones (1994), Mainwaring and Shugart (1995)--have included a code for presidential elections in investigations of legislative fractionalization. So do we. As our coding of this variable differs from these previous studies, however, we discuss it at some length.

The simplest way to code presidentialism is with a dummy variable ( 1 for presidential systems, 0 for parliamentary), as do Lijphart and Powell. The problem with this approach is that there are different kinds of presidential elections (runoff, plurality), held at different times relative to the legislative elections (concurrently, non-concurrently), and these factors plausibly matter. Thus, other scholars--such as Shugart and Carey (1992), Jones (1994), Shugart (1995), and Mainwaring and Shugart (1995)--have developed more elaborate schemes. Our approach, which follows Shugart and Carey in general conception but differs in the details of implementation, takes the influence a presidential election exerts on a legislative election as depending on two factors: the proximity of the two elections; and the degree of fractionalization of the presidential election. 
Proximity is a matter of degree. If the presidential and legislative elections are concurrent. then proximity is maximal. Here, we take the maximum value of proximity to be unity (so concurrent elections are "100\% proximal," so to speak). At the other end of the scale are legislative elections held in complete isolation from presidential elections--i.e., in nonpresidential systems. ${ }^{13}$ Such legislative elections are not at all proximal to a presidential election-so they are coded as of zero proximity. In between these two extremes are presidential systems with non-concurrent elections. If we denote the date of the legislative election by $\mathrm{L}_{1}$, the date of the preceding presidential election by $\mathrm{P}_{\mathrm{t}-1}$, and the date of the succeeding presidential election by $\mathrm{P}_{\mathrm{t}+1}$, then the proximity value is PROXIMITY $=2 *\left|\frac{L_{t}-P_{t-1}}{P_{t+1}-P_{t-1}}-\frac{1}{2}\right|$. This formula expresses the time elapsed between the preceding presidential election and the legislative election $\left(L_{t}-P_{1-1}\right)$, as a fraction of the presidential term $\left(\mathrm{P}_{\mathrm{t}^{+}+1}-\mathrm{P}_{\mathrm{t}-1}\right)$. Subtracting $1 / 2$ from this elapsed time fraction, and then taking the absolute value, shows how far away from the midterm the legislative election was held. The logic of the formula is as follows: The least proximal legislative elections are those held at midterm. This particular formula gives a proximity value of zero to these elections, which equates them with the totally isolated elections of non-presidential systems. ${ }^{14}$ The most proximal non-concurrent elections are those held just before or just after a presidential election. The formula above gives them a proximity value that approaches one, the same value given to concurrent elections. ${ }^{15}$

The proximity of the presidential election to the legislative election is a necessary condition for the former to influence the latter. But the nature of that influence depends on the nature of the presidential election. One approach to coding the nature of the presidential election is institutional. Mainwaring and Shugart (1995), for example, introduce variables that distinguish three classes of presidential elections: concurrent plurality, majority runoff, and other. Although we report some results in a footnote that follow this route, our approach is different. 
Our point of departure is the notion that both presidential and legislative election results convey information about the impact of social cleavages and electoral law's. To put it another way, if we denote the effective number of presidential candidates by ENPRES, and the effective number of elective parties in the legislative election by ENPV, then both ENPRES and ENPV may be thought of as dependent variables--products of social and electoral structure--along the lines of Figure 1.

There are three things to note about Figure 1. First, the picture assumes that the effect of the presidential election on the legislative election dominates that of the legislative election on the presidential: thus there is an arrow from ENPRES to ENPV but not one going in the reverse direction. In reality, there no doubt are reverse causal arrows of the kind omitted from Figure 1. But we believe that the direction of influence is primarily from executive to legislative elections, and making this assumption facilitates econometric estimation of the system of equations implied by Figure 1. In particular, one can first estimate an equation determining ENPRES and then estimate an equation--in which ENPRES appears as a regressor--determining ENPV (see below).

The second thing to note is that the influence of presidential on legislative elections is mediated through the effective number of presidential candidates, ENPRES, and does not include a direct impact of presidential rules on legislative fractionalization, as does the Mainwaring and Shugart formulation. Our justification for this runs as follows. Imagine a presidential election held under runoff rules that nonetheless--perhaps because the country is dominated by a single cleavage, perhaps for reasons idiosyncratic to the particular election--ends up as a two-way race. Given that there are just two candidates in the presidential race, we expect the same kind of influence as would be produced by an otherwise similar plurality race. The nature of the coattail opportunities that face legislative candidates should be similar, the nature of the advertising economies of scale that might be exploited should be similar, and so forth. It is hard to see why the presidential rules themselves, having failed to produce the expected result in the presidential race, would nonetheless exert some direct influence on the legislative race. Thus, we prefer to include ENPRES as a regressor in the equation for ENPV, rather than including descriptors of 
presidential election rules (these rules, of course. do have an indirect impact via their influence on ENPRES). All told, our expectation is that legislative elections that are highly proximal to presidential elections should have a lower effective number of parties, but how much lower should depend on ENPRES. Thus we include both PROXIMITY and PROXIMITY*ENPRES in the analysis. ${ }^{16}$

A final point to note about Figure 1 is that it presupposes an interaction between electoral and social structure, both in the production of ENPV and in the production of ENPRES. If there is such an interaction in legislative elections, as Ordeshook and Shvetsova (1994) claim, then there should also be an interaction in presidential elections.

Specifying the Equations. Having discussed the main differences of data and operationalization between our analysis and Ordeshook and Shvetsova's, we can turn to the issue of how we specify the relations of interest. We shall consider first the effective number of legislative parties (ENPS), then the effective number of elective parties (ENPV), and finally the effective number of presidential candidates (ENPRES). ${ }^{17}$

In investigating the first of these dependent variables (ENPS), we are interested in the purely mechanical features of how the legislative electoral system translates votes into seats. Accordingly, we include ENPV on the right-hand side (cf. Coppedge 1995). Indeed, in our view, the proper formulation is one in which ENPS would equal ENPV, were the electoral system perfectly proportional, with stronger electoral systems reducing ENPS below ENPV. Thus, we run the following regression:

$$
\operatorname{ENPS}=\alpha+\operatorname{ENPV}^{*}\left(\beta_{0}+\beta_{1} L M L+\beta_{2} \text { UPPER }\right)+\varepsilon
$$

If the electoral system employs single-member districts (so $L M L=0$ ) and has no upper tier (so UPPER $=0$ ), then it is maximally strong, and only a fraction $\beta_{0}$ of ENPV is added to $\alpha$ to give the predicted effective number of legislative parties in the system. As LML and UPPER increase, the system becomes more permissive and the fraction of ENPV that translates into seats should be greater. That is, the coefficients on ENPV*LML (i.e., $\beta_{1}$ ) and on ENPV*UPPER (i.e., $\beta_{2}$ ) should both be positive. One way to interpret this regression is simply as a check on the 
validity of our measures LML and UPPER. If LML properly measures the central tendency in lower-tier district magnitudes and UPPER really catches the impact of upper tiers, then the coefficients associated with both should be significant!

In the analysis of the effective number of elective parties. ENPV, we run five specifications: a pure institutionalist specification, with only variables pertaining to the legislative electoral system or the impact of presidential elections; a pure sociological model, with only a variable tapping into social heterogeneity (specifically, ENETH, the effective number of ethnic groups, used by Ordeshook and Shvetsova), ${ }^{18}$ an additive model in which both sets of variables are included; an additive/interactive model in which an interaction term (between LML and ENETH) is added to the previous specification; and an interactive model in which the linear terms for LML and ENETH are omitted but the interaction term LML*ENETH is kept.

Finally, our analysis of the effective number of presidential candidates is as suggested in Figure 1. The main regressors are a dummy variable identifying runoff systems (RUNOFF), the effective number of ethnic groups (ENETH), and their interaction (RUNOFF*ENETH).

\section{Results}

Our results are displayed in Tables 1,2 and 3. Table 1 shows, not surprisingly, that a fair amount of the variance $(93 \%)$ in the effective number of parliamentary parties can be explained by just ENPV and interactions between ENPV and two indicators of the strength of the electoral system--LML and UPPER. All variables have the expected sign and are statistically discemible from zero at about the .001 level or better. One way to explain the substantive impacts implied by the results in Table 1 is to compare two hypothetical systems, in neither of which there is an upper tier. System $A$ has single-member districts, hence $L M L=0$. System B has ten-seat districts, hence $\mathrm{LML}=2.3$. Suppose that both systems have ENPV $=3$ in a particular election. The stronger system (A) is predicted to reduce this number of elective parties by almost a full (effective) party, to 2.09 (shades of the U.K. in the 1980s!). The weaker system (B) is predicted 
to reduce the three effective parties competing in the election by much less, to 2.64 legislative parties. The substantive importance of this difference might vary from situation to situation, but it certainly suggests an important change from essentially a two-party legislative system with mostly single-party governments to a two-and-a-half or three-party legislative system with coalition governments as the norm. ${ }^{19}$

[Table 1 about here.]

The results in Table 2 show the results for the five equations estimating the effective number of elective parties (ENPV) outlined in the previous section. In running these regressions, we have omitted electoral systems with fused votes--that is, systems in which the voter casts a single vote for a slate which includes candidates for executive and legislative offices. The reason for omitting such systems is that they change the meaning of essentially all the institutional regressors. For example, do voters in such systems respond to the district magnitude at the legislative level or at the presidential level? Fused-vote systems really need to be analyzed separately (see Shugart 1985 for the case of Venezuela, which has a fused vote for senate and house races) but we do not attempt to do so here: we just omit the three cases of executivelegislative fused votes in our sample--Bolivia, Honduras, and Uruguay. ${ }^{20}$ This reduces our number of observations to 51 for the regressions in Table 2 . We shall discuss each briefly in turn.

The first model, with only institutional variables, explains about $61 \%$ of the variance in our sample of ENPV values. All coefficients are of the expected sign and significant at the .05 level or better. The second model, with only the effective number of ethnic groups (ENETH) as a regressor, produces a poor fit (an adjusted $\mathrm{R}^{2}$ of .01 ) and an insignificant coefficient and regression. The third model, which combines the regressors from the first two, shows little change in the coefficients of the institutional variables but produces a coefficient on ENETH that is statistically significant at the .05 level. Apparently, proper controls for electoral structure are 
important in discerning any independent additive effect due to ethnic heterogeneity. The fourth model--which adds to the third an interaction term, LML*ENETH--reduces the coefficients on LML and ENETH to statistically insignificant values, while producing a substantial and statistically significant positive coefficient on the interaction term (LML*ENETH), together with little change in the coefficients of the remaining variables. Finally, the fifth model, in which the variables LML and ENETH are omitted, but their interaction is retained, produces a somewhat smaller interaction coefficient (but a substanitally smaller interaction standard error), with other coefficients largely unchanged. If one chooses among specifications according to which produces the largest adjusted $\mathrm{R}^{2}$ (not necessarily recommended; see the discussion in Kennedy 1994), then the last specification--with an adjusted $R^{2}$ of .69--is the best.

[Table 2 about here.]

We have also investigated a different formulation for the interactive term, using the minimum of LML and ENETH instead of their product. Substituting this minimum term for LML*ENETH in the last model produces little change in any of the other coefficients or in the overal fit of the equation. It is thus difficult on the basis of this study to say much one way or another about whether the form of the interaction should be thought of as a product or a minimum..$^{21}$

Finally, Table 3 displays results for three regressions that take ENPRES as the dependent variable. The first model is additive, using RUNOFF and ENETH as regressors. As can be seen, neither regressor is statistically significant and the regression as a whole sports a negative adjusted $\mathrm{R}^{2}$ (regressions with just RUNOFF and just ENETH are also insignificant). The second model adds the interaction term, RUNOFF*ENETH, to the first. The linear terms remain insignificant (albeit reversing sign) but the interaction term is appropriately signed and significant. The last model drops the linear terms, keeping only the interaction; the coefficient on 
the interaction term is again positive and statistically discernible from zero in a one-tailed test at the .05 level.

[Table 3 about here.]

Two questions that might arise about the series of results just presented are whether our results hold for other measures of social diversity and whether our results hold both for the mostly-European industrialized democracies (investigated in previous studies) and for the mostly-non-European developing democracies (that we have added to the analysis). The answer to both questions is affirmative. If, instead of the effective number of ethnic groups, one uses the effective number of language groups as a measure of social diversity, one finds qualitatively similar results. ${ }^{22}$ If one removes the 20 mostly-European democracies studied by Rae (1971), Lijphart (1990), and Ordeshook and Shvetsova (1994) from the analysis, leaving a sample of 34 mostly non-European developing countries, one again finds qualitatively similar results in all analyses..$^{23}$

\section{Conclusion}

The results presented in the previous section pertaining to legislative elections are remarkably similar to those generated by Ordeshook and Shvetsova (1994). Despite using a different data set--one that included many new and developing democracies rather than concentrating on the long-term democracies--and despite several differences in operationalization and specification, the basic result holds up: the effective number of parties appears to depend on the product of social heterogeneity and electoral permissiveness, rather than being an additive function of these two factors. ${ }^{24}$ The intuitive formulation of this finding is that a polity can tend toward bipartism either because it has a strong electoral system or because it has few cleavages. 
Multipartism arises as the joint product of many exploitable cleavages and a permissive electoral system.

If this general conclusion is valid, it ought to hold, not just for elections to the lower house of the national legislature, but also for other elections. And we do find a bit of evidence consistent with the notion that the effective number of presidential candidates is an interactive product of social and electoral structure. In particular, elections that are both held under more permissive rules (runoff rather than plurality) and occur in more diverse societies (with a larger effective number of ethnic groups) are those that tend to have the largest fields of contestants for the presidency.

It is worth discussing why this finding--that the size of the party system depends interactively on social and electoral structure--is important and has merited the effort of reexamination and extension. First, it clearly differs from the more purely sociological formulations noted at the outset of the paper, in which the cleavage structure drives both the choice of an electoral system and the number of parties. For, under such a formulation, a polity with many cleavages always chooses a permissive electoral system, so that the strength of the electoral system should have had no discernible impact after controlling for the cleavage structure. The measure of cleavage structure employed here is crude, so that one cannot confidently reject the purely sociological approach based on this study, but certainly our results lend no support.

Second, that there is an interaction between electoral strength and social heterogeneity in the genesis of political parties also argues against purely institutionalist approaches. Consider, for example, Lijphart's (1994) magisterial examination of changes in post-war democratic electoral systems and the subsequent changes in number of parties. Often he found that increases in the permissiveness of an electoral system did not subsequently give rise to an increase in the number of parties. On a purely institutionalist account, this would count against the importance of electoral law. Taking account of the interaction between social and electoral structure, however, finding no increase in the number of parties after increasing the permissiveness of the 
electoral system counts as evidence against the importance of electoral structure only if one believes that the previous electoral system had impeded the exploitation of extant cleavages in the society, so that it was actually holding the number of parties below what it would be with a more permissive system. Absent such a belief, one would not expect a weakening of the electoral system to lead to increases in the number of parties, and so one would not count failure to observe such an increase as evidence of the frailty of electoral laws in conditioning political life. Similarly, finding that an increase in the strength of an electoral system does not produce a contraction in the party system is telling evidence only if the number of parties under the old system exceeds the "carrying capacity" of the new system.

Finally, we should note some directions for further research that our work suggests. One follows directly from the remarks just made: perhaps there is room for a reanalysis of Lijphart's findings with social heterogeneity taken into account. Another follows from a question posed but left unanswered above: what precisely should the form of the interaction between social and electoral structure be? To address this question would require a substantially larger dataset than that we have compiled here. A third possible direction for research follows from the general observation that electoral studies ought to move toward constituency-level evidence (e.g., Taagepera and Shugart 1989, pp. 213-14; Cox and Shugart 1991). Clearly the key electoral factors (e.g., district magnitude) can vary widely within a given nation. Just as clearly, it is also possible to find substantial variation across a given nation's electoral constituencies in ethnic, linguistic and religious heterogeneity. These observations suggest that it may be fruitful in further investigations of the interaction (or lack thereof) between social and electoral structure, to use constituency-level electoral returns and constituency-level indicators of social diversity. 
Appendix: Data and Sources

\section{COUNTRY}

Year ENPV ENPS ML UPPER PROXIMITY ENPRES ENETH

\begin{tabular}{|c|c|c|c|c|c|c|c|c|}
\hline Argentina & 1985 & 3.37 & 2.37 & 9.0 & 0.00 & 0.55 & 2.51 & 1.34 \\
\hline Australia & 1984 & 2.79 & 2.38 & 1.0 & 0.00 & 0.00 & & 1.11 \\
\hline Austria & 1986 & 2.72 & 2.63 & 30.0 & 0.11 & 0.80 & 2.27 & 1.01 \\
\hline Bahamas & 1987 & 2.11 & 1.96 & 1.0 & 0.00 & 0.00 & . & 1.34 \\
\hline Barbados & 1986 & 1.93 & 1.25 & 1.0 & 0.00 & 0.00 & . & 1.50 \\
\hline Belgium & 1985 & 8.13 & 7.01 & 8.0 & 0.40 & 0.00 & . & 2.35 \\
\hline Belize & 1984 & 2.06 & 1.60 & 1.0 & 0.00 & 0.00 & . & 3.46 \\
\hline Bolivia & 1985 & 4.58 & 4.32 & 17.5 & 0.00 & 1.00 & 4.58 & 3.77 \\
\hline Botswana & 1984 & 1.96 & 1.35 & 1.0 & 0.00 & 0.00 & . & 1.11 \\
\hline Brazil & 1990 & 9.68 & 8.69 & 30.0 & 0.00 & 0.63 & 5.69 & 2.22 \\
\hline Canada & 1984 & 2.75 & 1.69 & 1.0 & 0.00 & 0.00 & $\therefore$ & 3.49 \\
\hline Colombia & 1986 & 2.68 & 2.45 & 8.0 & 0.00 & 0.93 & 2.13 & 2.51 \\
\hline Costa Rica & 1986 & 2.49 & 2.21 & 10.0 & 0.00 & 1.00 & 2.07 & 1.08 \\
\hline Cyprus & 1985 & 3.62 & 3.57 & 12.0 & 0.00 & 0.00 & $\cdot$ & 1.56 \\
\hline Czech Republic* & 1990 & 3.10 & 2.04 & 24.0 & 0.05 & 0.00 & . & 1.12 \\
\hline Denmark & 1984 & 5.25 & 5.04 & 11.0 & 0.00 & 0.00 & . & 1.02 \\
\hline Dominica & 1985 & 2.10 & 1.76 & 1.0 & 0.00 & 0.00 & . & 1.68 \\
\hline Dominican Republic & 1986 & 3.19 & 2.53 & 5.0 & 0.00 & 1.00 & 2.80 & 1.75 \\
\hline El Salvador & 1985 & 2.68 & 2.10 & 4.0 & 0.00 & 0.64 & 3.16 & 1.25 \\
\hline Equador & 1984 & 10.32 & 5.78 & 3.0 & 0.00 & 1.00 & 5.18 & 2.60 \\
\hline Finland & 1983 & 5.45 & 5.14 & 17.0 & 0.00 & 0.61 & 3.79 & 1.13 \\
\hline France & 1981 & 4.13 & 2.68 & 1.0 & 0.00 & 0.96 & 4.86 & 1.17 \\
\hline Germany & 1983 & 3.21 & 3.16 & 1.0 & 0.50 & 0.00 & . & 1.15 \\
\hline Greece & 1985 & 2.59 & 2.14 & 6.0 & 0.24 & 0.00 & . & 1.04 \\
\hline Grenada & 1990 & 3.84 & 3.08 & 1.0 & 0.00 & 0.00 & . & 1.06 \\
\hline Honduras & 1985 & 3.49 & 2.80 & 9.0 & 0.00 & 1.00 & 3.49 & 1.23 \\
\hline Iceland & 1983 & 4.26 & 4.07 & 7.0 & 0.18 & 0.41 & 3.60 & 1.06 \\
\hline India & 1984 & 3.98 & 1.69 & 1.0 & 0.00 & 0.00 & . & 1.72 \\
\hline Ireland & 1987 & 3.46 & 2.89 & 5.0 & 0.00 & 0.00 & . & 1.08 \\
\hline Israel & 1984 & 4.28 & 3.86 & 120.0 & 0.00 & 0.00 & . & 1.39 \\
\hline Italy & 1983 & 4.51 & 4.11 & 24.0 & 0.11 & 0.00 & . & 1.04 \\
\hline Jamaica & 1989 & 1.97 & 1.60 & 1.0 & 0.00 & 0.00 & . & 1.65 \\
\hline Japan & 1986 & 3.35 & 2.57 & 4.0 & 0.00 & 0.00 & & 1.01 \\
\hline Korea (South) & 1988 & 4.22 & 3.56 & 1.0 & $0.25^{* *}$ & 0.87 & 3.55 & 1.01 \\
\hline Liechtenstein & 1986 & 2.28 & 1.99 & 15.0 & 0.00 & 0.00 & . & 1.11 \\
\hline Luxembourg & 1984 & 3.56 & 3.22 & 21.0 & 0.00 & 0.00 & . & 1.63 \\
\hline Malta & 1987 & 2.01 & 2.00 & 5.0 & 0.00 & 0.00 & . & 1.13 \\
\hline Mauritius & 1983 & 1.96 & 2.16 & 3.0 & 0.00 & 0.00 & . & 1.86 \\
\hline Netherlands & 1986 & 3.77 & 3.49 & 150.0 & 0.00 & 0.00 & . & 1.08 \\
\hline New Zealand & 1984 & 2.99 & 1.98 & 1.0 & 0.00 & 0.00 & . & 1.28 \\
\hline Norway & 1985 & 3.63 & 3.09 & 10.0 & 0.00 & 0.00 & & 1.04 \\
\hline Peru & 1985 & 3.00 & 2.32 & 9.0 & 0.00 & 1.00 & 2.76 & 2.76 \\
\hline Portugal & 1983 & 3.73 & 3.41 & 16.0 & 0.00 & 0.05 & 1.96 & 1.02 \\
\hline Spain & 1986 & 3.59 & 2.81 & 7.0 & 0.00 & 0.00 & . & 1.65 \\
\hline St.Kints and Nevis & 1984 & 2.45 & 2.46 & 1.0 & 0.00 & 0.00 & & 1.22 \\
\hline St.Lucia & 1987 & 2.32 & 1.99 & 1.0 & 0.00 & 0.00 & & .22 \\
\hline
\end{tabular}




$\begin{array}{lrrrrrrrr}\text { St.Vincent \&Grenadines } & 1984 & 2.28 & 1.74 & 1.0 & 0.00 & 0.00 & . & 1.66 \\ \text { Sweden } & 1985 & 3.52 & 3.39 & 12.0 & 0.00 & 0.00 & . & 1.26 \\ \text { Switzerland } & 1983 & 5.99 & 5.26 & 12.0 & 0.00 & 0.00 & . & 2.13 \\ \text { Trinidad \& Tobago } & 1986 & 1.84 & 1.18 & 1.0 & 0.00 & 0.00 & . & 2.74 \\ \text { United Kingdom } & 1983 & 3.12 & 2.09 & 1.0 & 0.00 & 0.00 & . & 1.48 \\ \text { United States } & 1984 & 2.03 & 1.95 & 1.0 & 0.00 & 1.00 & 1.96 & 1.36 \\ \text { Uruguay } & 1989 & 3.38 & 3.35 & 11.0 & 0.27 & 1.00 & 3.38 & 1.28 \\ \text { Venezuela } & 1983 & 2.97 & 2.42 & 11.0 & 0.09 & 1.00 & 2.19 & 1.99\end{array}$

\section{Notes:}

$\left({ }^{*}\right)$ The Czech Republic was not of course an independent state in 1990. We use the Czech results from the Czechoslovak election of that year. Omitting this case does not affect our results.

$\left({ }^{* *}\right)$ South Korea's upper tier is not compensatory and so in our main results we do not handle it in the same way as the other systems with upper tiers (see footnote 11).

(1) $\mathrm{ENPV}=1 / \sum v_{i}^{2}$, where $\mathrm{v}_{\mathrm{i}}$ is party i's vote share in the legislative election; the effective number of elective parties.

(2) ENPS $=1 / \sum s_{1}^{2}$, where $s_{i}$ is party i's seat share in the legislature; the effective number of legislative parties.

(3) $\mathrm{ML}$ is the magnitude of the median legislator's district. If there are $\mathrm{N}$ members of a given country's legislature, one can associate with each member the magnitude of the electoral district from which that member was elected. Taking the median of these N numbers then gives ML. We take the median rather than the average because the former is a more robust measure of central tendency, although in practice the two measures work similarly. Data to compute ML come from Cox 1995.

(4) UPPER: see below.

(5) PROXIMITY: as defined in text.

(6) ENPRES $=1 / \sum p_{t}^{2}$, where $p_{i}$ is party $i$ 's vote share in the presidential election; the effective number of presidential candidates.

(7) ENETH $=1 / \sum g_{1}^{2}$, where $g_{i}$ is the proportion of the population in ethnic group $i$; the effective number of ethnic groups. 
Appendix, continued: Upper Tier Variable

Percentage of Seats Allocated at the Upper Tier Level

$\begin{array}{cccc}\text { Country } & \begin{array}{c}\text { Election } \\ \text { Year }\end{array} & \begin{array}{c}\text { Assembly } \\ \text { Size }\end{array} & \frac{\text { Seats Awarded in Upper Tier }}{\mathrm{N}} \\ \%\end{array}$

\begin{tabular}{lrrrr}
\hline Austria & 1986 & 183 & 21 & 11.4 \\
Belgium & 1985 & 212 & 85 & 40.0 \\
Czech Republic & 1990 & 101 & 5 & 5.0 \\
Germany & 1983 & 498 & 248 & 49.8 \\
Greece & 1985 & 232 & 56 & 24.1 \\
Iceland & 1983 & 60 & 11 & 18.3 \\
Italy & 1983 & 630 & 72 & 11.4 \\
Uruguay & 1989 & 99 & 27 & 27.2 \\
Venezuela & 1983 & 200 & 18 & 9.0 \\
& & & & \\
\hline
\end{tabular}

Sources:

Austria - Bunsdesministerium fur Inneres. 1987. Die Nationalratswahl vom 23 November 1986. Wien: Druck und Kommissionsverlag der Osterreichischen Staatsdruckerei.

Belgium - Ministère de L'Intérieur et de la FonctionPublique. (N.d.). Élections Législatives $d u$ 13 Octobre 1985 - Chambre des Représentants. Ministère de L'Intérieur et de la Fonction Publique.

Czech Republic - Wightman, Gordon. 1990. "Czechoslovakia." Electoral Studies 9:319-26.

Germany - Lijphart, Arend. 1994. Electoral Systems and Party Systems: A Study of TwentySeven Democracies, 1945-1990. Oxford: Oxford University Press.

Greece - $i$ bid.

Iceland - Mackie, Thomas T. and Richard Rose. 1991. The International Almanac of Electoral History, 3rd. ed. Washington, D.C.: Congressional Quarterly.

Italy - Instituto Centrale di Statistica. 1984. Elezioni della Camera dei Deputati e del Senato della Repubblica - 26 Giugno 1983. Roma: Ministèro Dell'Interno.

Uruguay - Albomoz, Alfredo. 1992. Elecciones. Montevideo: Cámara de Representantes.

Venezuela - Consejo Supremo Electoral. 1987. Los Partidos Politicos y Sus Estadisticas Electorales. Caracas: Consejo Supremo Electoral - División de Estadística. 


\section{References}

Arms, Thomas S., and Eileen Riley, eds. 1987. World Elections on File. New York: Facts on File.

Brazil - Tribunal Superior Eleitoral. 1990. Resultado das Eleições de 1990 para a Câmara dos Deputados. Brasilia: Supervisão de Engenharia de Sistemas do Tribunal Superior Eleitoral.

Caims, A. 1968. "The Electoral System and the Party System in Canada, 1921-1965." Canadian Journal of Political Science 1:55-80.

Campbell, Peter. 1958. French Electoral Systems and Elections 1789-1957. London: Faber and Faber.

Central Intelligence Agency. 1990. World Factbook. Washington, D.C.: Central Intelligence Agency.

Central Intelligence Agency. 1994. World Factbook. Washington, D.C.: Brassey's.

Coppedge, Michael. 1995. "District Magnitude, Economic Performance, and Party-System Fragmentation in Five Latin American Countries." University of Notre Dame. Unpublished manuscript.

Cox, Gary W. 1994. "Strategic Voting Equilibria under the Single Non-Transferable Vote." American Political Science Review 88:608-21. 
Cox, Gary W. 1995. The Politics of Electoral Coalition. University of Califormia, San Diego. Unpublished book manuscript.

Cox, Gary W., and Matthew S. Shugart. 1991. "Comment on Gallagher`s 'Proportionality, Disproportionality and Electoral Systems'." Electoral Studies 10:348-52.

Cox, Gary W., and Matthew S. Shugart. 1995. "Strategic Voting Under Proportional Representation." University of California, San Diego. Unpublished manuscript.

Cox, Gary W., and Matthew S. Shugart. N.d. "In the Absence of Vote Pooling: Nomination and Vote Allocation Errors in Colombia." Electoral Studies. Forthcoming.

Duverger, Maurice. 1954. Political Parties. New York: Wiley.

Encyclopedia Britannica. 1980. Chicago: Encyclopedia Britannica.

Eckstein, H. 1963. "The Impact of Electoral Systems on Representative Government." In Comparative Politics: A Reader, ed. H. Eckstein and D. Apter. New York: Free Press.

Franco, Rolando. 1986. "El Sistema Electoral Uruguayo en un Perspectivo Comparada." In $E l$ Sistema Electoral Uruguayo: Peculiaridades y Perspectivas, ed. Rolando Franco. Montevideo: Fundación Hanns-Seidel.

Freedom House. 1980-1991. Freedom in the World. New York: Freedom House.

Fukui, Haruhiro. 1988. "Electoral Laws and the Japanese Party System." In Japan and the World, ed. Gail Lee Bernstein and Haruhiro Fukui. London: Macmillan. 
Gallagher, Michael, Michael Laver and Peter Mair. 1992. Representative Government in Western Europe. New York: McGraw-Hill.

Gorwin, Ian, ed. 1989. Elections Since 1945. A Worldwide Reference Compendium. Essex: Longman.

Grumm, J. G. 1958. "Theories of Electoral Systems." Midwest Journal of Political Science 2:357-76.

Jesse, Eckhard. 1990. Elections: The Federal Republic of Germany in Comparison. Trans. Lindsay Batson. New York: St. Martin's.

Jones, Mark P. 1994. "Presidential Election Laws and Multipartism in Latin America." Political Research Quarterly 47:41-57.

Jones, Mark P. 1995. "A Guide to the Electoral Systems of the Americas." Electoral Studies 14:5-21.

Kennedy, Peter. 1994. A Guide to Econometrics. 3rd edition. Cambridge: MIT Press.

Kim, Jae-On, and Mahn-Geum Ohn. 1992. "A Theory of Minor-Party Persistence: Election Rules, Social Cleavage, and the Number of Political Parties." Social Forces 70:575-99.

Laakso, Marku, and Rein Taagepera. 1979. "Effective Number of Parties: A Measure with Application to West Europe." Comparative Political Studies 12:3-27.

Lavau, G. E. 1953. Partis Politiques et Réalités Sociales. Paris: A. Colin. 
Lijphart, Arend. 1990. "The Political Consequences of Electoral Law's. 1945-85." American Political Science Review 84:481-96.

Lijphart, Arend. 1994. Electoral Systems and Party Systems: A Study of Twenty-Seven Democracies, 1945-1990. Oxford: Oxford University Press.

Lipset, Seymour Martin, and Stein Rokkan, eds. 1967. Party Systems and Voter Alignments: Cross-National Perspectives. New York: Free Press.

Lipson, Leslie. 1959. "Party Systems in the United Kingdom and the Older Commonwealth: Causes, Resemblances, and Variations." Political Studies 7:12-31.

Lipson, Leslie. 1964. The Democratic Civilization. New York: Oxford University Press.

Mackie, Thomas T., and Richard Rose. 1991. The International Almanac of Electoral History. 3rd. ed. Washington, D.C.: Congressional Quarterly.

Mainwaring, Scott, and Matthew S. Shugart. 1995. "Conclusion: Presidentialism and the Party System." In Mainwaring, Scott, and Matthew S. Shugart, eds. Presidentialism and Democracy in Latin America. Unpublished book manuscript, University of California, San Diego.

Meisel, John. 1963. "The Stalled Omnibus: Canadian Parties in the 1960s." Social Research $30: 383-4$.

Myerson, Roger, and Robert Weber. 1993. "A Theory of Voting Equilibria." American Political Science Review 87:102-14. 
Nagel, Jack H. 1994. "Predicting the Political Consequences of Electoral Reform: How Many Parties Will New Zealand Have Under Proportional Representation?" Paper presented at the annual meeting of the American Political Science Association, New York.

Nohlen, Dieter, ed. 1993. Enciclopedia Electoral Latinoamericana y del Caribe. San José: Instituto Interamericano de Derechos Humanos.

Olson, Mancur. 1965. The Logic of Collective Action. Cambridge, MA: Harvard University Press.

Ordeshook, Peter, and Olga Shvetsova. 1994. "Ethnic Heterogeneity, District Magnitude, and the Number of Parties." American Journal of Political Science 38:100-23.

Palfrey, Thomas. 1989. "A Mathematical Proof of Duverger's Law." In Models of Strategic Choice in Politics, ed. Peter C. Ordeshook. Ann Arbor: University of Michigan Press.

Powell, G. Bingham. 1982. Contemporary Democracies: Participation, Stability and Violence. Cambridge: Harvard University Press.

Rae, Douglas. 1971. The Political Consequences of Electoral Laws. Rev. ed. New Haven, CT: Yale University Press.

Riker, William H. 1982. "The Two-Party System and Duverger's Law: An Essay on the History of Political Science." American Political Science Review 76:753-66.

Rokkan, Stein. 1970. Citizens, Elections, Parties. New York: Mackay. 
Rose, Richard, and Derek Urwin. 1970. "Persistence and Change in Western Party Systems since 1945." Political Studies 18:287-319.

Santos, Wanderley Guilherme dos, ed. 1990. Que Brasil é Este? Manual de Indicadores Politicos e Sociais. São Paulo: Vértice.

Särlvik, Bo. 1983. "Scandinavia." In Democracy and Elections: Electoral Systems and Their Political Consequences, ed. Vernon Bogdanor and David Butler. Cambridge: Cambridge University Press.

Sartori, Giovanni. 1968. "Political Development and Political Engineering." In Public Policy, ed. John D. Montgomery and Albert O. Hirschman. Cambridge: Cambridge University Press.

Sartori, Giovanni. 1976. Parties and Party Systems: A Framework of Analysis. Cambridge: Cambridge University Press.

Schattschneider, Elmer Eric. 1960. The Semisovereign People: A Realist's View of Democracy in America. New York: Holt, Rinehart and Winston.

Singh V. B., and Bose Shankar. 1986. Elections in India: Data Handbook on Lok Sabha Elections, 1952-85. New Delhi: Sage Publications.

Shugart, Matthew S. 1985. "The Two Effects of District Magnitude: Venezuela as a Crucial Experiment." European Journal of Political Research 13:353-64. 
Shugart, Matthew S. 1995. "The Electoral Cycle and Institutional Sources of Divided Presidential Government." American Political Science Review 89:327-43.

Shugart, Matthew S., and John M. Carey. 1992. Presidents and Assemblies. Constitutional Design and Electoral Dynamics. New York: Cambridge University Press.

Solari, Aldo E. 1986. "El Sistema de Partidos y Régimen Electoral en el Uruguay." In El Sistema Electoral Uruguayo: Peculiaridades y Perspectivas, ed. Rolando Franco Montevideo: Fundación Hanns-Seidel.

Taagepera, Rein, and Bernard Grofman. 1985. "Rethinking Duverger's Law: Predicting the Effective Number of Parties in Plurality and PR Systems -- Parties Minus Issues Equals One." European Journal of Political Research 13:341-52.

Taagepera, Rein, and Matthew Soberg Shugart. 1989. Seats and Votes: The Effects and Determinants of Electoral Systems. New Haven: Yale University Press.

Vanhanen, Tatu. 1990. The Process of Democratization. A Comparative Study of 147 States (1980-88). New York: Crane Russak.

Worldmark Encyclopedia of the Nations. 1984. New York: John Wiley. 
Table 1: The Determinants of the

Effective Number of Legislative Parties

Dependent Variable: ENPS

Independent

Estimated

Standard

Variables

Coefficients

Errors

CONSTANT

.582

.135

ENPV

.507

.048

ENPV*LML

.080

.012

ENPV*UPPER

.372

.111

Adjusted $\mathrm{R}^{2}=$

.921

$\mathrm{N}$ of Obs $=$ 
Table 2: The Determinants of the Effective Number of Electoral Parties

Dependent Variable: ENPV

Independent

Variables

Model

\begin{tabular}{|c|c|c|c|c|c|}
\hline \multirow[t]{2}{*}{ CONSTANT } & 2.44 & 2.76 & 1.61 & 2.45 & 2.40 \\
\hline & $(.25)$ & $(.66)$ & $(.47)$ & $(.55)$ & $(.21)$ \\
\hline \multirow[t]{2}{*}{ LML } & .48 & - & .52 & -.23 & - \\
\hline & $(.11)$ & & $(.11)$ & $(.31)$ & \\
\hline \multirow[t]{2}{*}{ UPPER } & 3.64 & -- & 3.95 & 3.46 & 3.51 \\
\hline & $(1.52)$ & & (1.48) & $(1.40)$ & $(1.37)$ \\
\hline \multirow[t]{2}{*}{ PROXIMITY } & -5.98 & -- & -5.95 & -6.01 & -6.04 \\
\hline & $(.97)$ & & $(.94)$ & $(.89)$ & $(.88)$ \\
\hline \multirow[t]{2}{*}{ PROXIMITY * ENPRES } & 2.18 & -- & 2.14 & 2.05 & 2.09 \\
\hline & $(.29)$ & & $(.28)$ & $(.26)$ & $(.26)$ \\
\hline \multirow[t]{2}{*}{ ENETH } & - & .49 & .51 & .01 & -- \\
\hline & & $(.40)$ & $(.25)$ & $(.30)$ & \\
\hline \multirow[t]{2}{*}{ LML*ENETH } & - & -- & -- & .53 & .39 \\
\hline & & & & $(.21)$ & $(.07)$ \\
\hline Adjusted $\mathrm{R}^{2}=$ & .613 & .01 & .639 & .679 & .686 \\
\hline $\mathrm{N}=$ & 51 & 51 & 51 & 51 & 51 \\
\hline
\end{tabular}


Table 3: The Determinants of the Effective Number of Presidential Candidates

Dependent Variable: ENPRES

Independent

Variables

Model



CONSTANT

$\begin{array}{lll}2.26 & 4.30 \quad 2.68\end{array}$

$(.87) \quad(1.23)$

RUNOFF

$.63 \quad-2.49$

(.61) (1.56)

ENETH

$\begin{array}{ll}.37 & -.98 \\ (.50) & (.77)\end{array}$

RUNOFF*ENETH

$\begin{array}{rrr}- & 2.01 & .58 \\ & (.94) & (.29)\end{array}$

Adjusted $\mathrm{R}^{2}=$

$-.015$

.202

.171

$\mathrm{N}=$

16

16

16 
Figure 1: A Schematic Representation of the Relationship Between Social Cleavages, Rules of Election, and Number of Competitors in Presidential and Legislative Elections

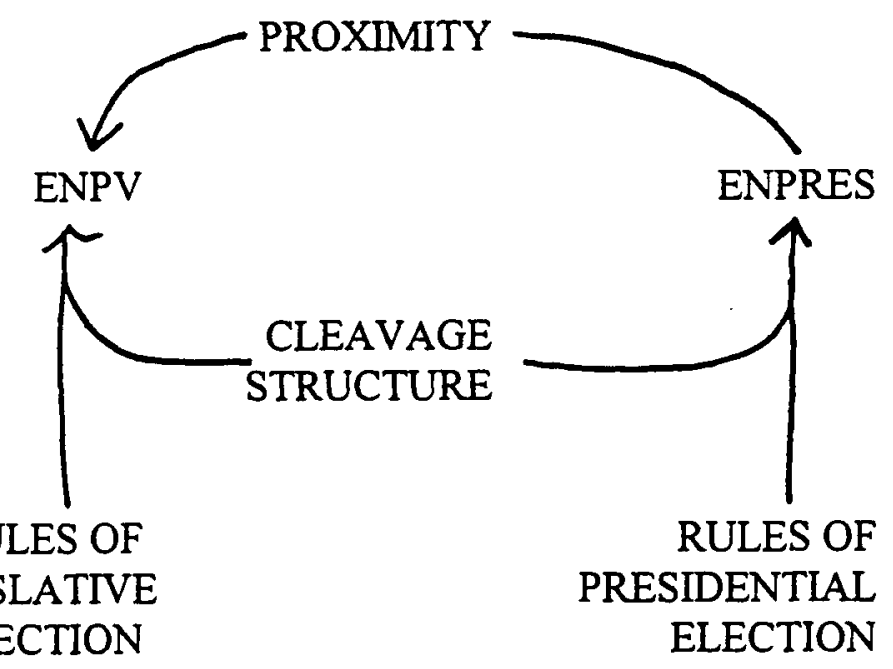




\section{ENDNOTES}

1. In this view. party systems determine electoral systems, rather than the other way around; cf. Grumm 1958; Eckstein 1963. p. 253: Lipson 1964; Särlvik 1983, p. 123; Fukui 1988, p. 121.

2. Cf. Lavau 1953, p. 46; Campbell 1958, pp. 30-32; Grumm 1958; Lipson 1959; Meisel 1963; Lipson 1964; Lipset and Rokkan 1967; Rokkan 1970; Franco 1986, pp. 82-3; Solari 1986, pp. 120-21. In perhaps the earliest retort of this kind to Duverger's theses, Lavau (1953, p. 46) opined that "le mode de scrutin demeure une bien petite chose en regard des facteurs complexes et infiniment divers qui, combinés différemment dans chaque société nationale..., conditionnent la vie politique."

3. By listing these criticisms, we do not mean to imply that the side criticized has not recognized the problem and sought to deal with it. Adherents of the sociological approach, for example, have recognized the collective action problems inherent in translating social cleavages into political party cleavages (e.g., Rose and Urwin, Meisel), while adherents of the institutionalist approach have addressed the endogeneity of institutional structure (e.g., Riker 1982; Cox 1995).

4. By social cieavages we mean enduring social differences that might become politicized, or might not: differences of ethnicity, religion, language, or occupation, for example. Often, the notion of a social cleavage carries more than just this base notion of "socially-defined difference." Gallagher, Laver and Mair (1992, p. 90), for example, define a social cleavage as a social division in which the groups involved are conscious of their collective identity, partly because their is an organization (church, union, etc.) that gives expression to this identity.

5. The reduction of possible to launched parties depends on many things: the level of pre-existing non-political organization that can be turned to political advantage; monetary resources; media access; and so on. Thus, a religious cleavage with well-organized and well-financed churches on both sides (e.g., Evangelicals versus Pietists in the nineteenth-century U.S.) is more likely to be politically activated, other things equal, than a racial cleavage in which one side is poorly organized and poorly financed (e.g., whites versus Aborigines in Australia).

6 . Other studies that share the same basic conception, but do not run regressions with explicit measures of both electoral and social structure, include Nagel (1994) and Coppedge (1995).

7. Two control variables--population (in millions, as of 1965) and GNP per capita (as of 1965)--are also included. 
8. An additive combination model--such as Powell's--allow's the number of parties to be large either because there are many cleavages (regardless of how strong the electoral system is) or because the electoral system is very permissive (regardless of how few cleavages there are).

9. A copy of the full dataset, along with SAS code that reads and analyzes the data, can be found under the "publication-related datasets" heading of the Lijphart Elections Archive at http://ssdc.ucsd.edu/lij (or http://ssdc.ucsd.edu/lij/charbase for character-based browsers).

10. The only exceptions to these rules are as follows. First, we have not included any of the Pacific Island states (e.g., Tuvalu, Solomon Islands) because we could not get complete data. Hungary (1990) is excluded for the same reason. Finally, we take the 1990 Brazilian election rather than the (unusual) 1986 election.

". The South Korean upper tier is designed to ensure that the largest party can secure a majority, or a near-majority, in the legislature--and thus in principle it reduces proportionality. Our results do not change appreciably depending on how we code South Korea. Nor do they change if South Korea is simply omitted from the analysis.

12. In deciding whether a system is presidential or not, we have followed Shugart and Carey 1992, ch. 8. Ireland, for example, in which the president has neither legislative nor governmental powers, is coded as non-presidential. All systems in which the president has either legislative, or governmental, or both kinds of powers are coded as presidential.

13. It is possible to include an additional parameter to test whether midterm elections are significantly more affected by presidential politics than elections occurring in non-presidential systems. We have done so and found that one cannot reject the hypothesis that midterm and non-presidential elections are equally unaffected by presidential elections.

14. With the current dataset, it is difficult to test Shugart's (1995) hypothesis that there is a jump between nearly concurrent and exactly concurrent elections--with the depressive effect of presidential elections being much larger in the latter--since there are only five observations on concurrent elections. Some limited exploration--replacing the value " 2 " in the definition of PROXIMITY given in the text by "1.9" and other lower values--suggests that the main results of the paper do not depend on how one handles this issue.

15. Our data on presidential structure are culled from Jones (1995), Mackie and Rose (1991), Nohlen (1993), and Santos (1990). 
16. Our data on votes and seats (at the national level) were culled from Arms and Eileen (1987), Brazil - Tribunal Superior Eleitoral (1990), Gorwin (1989), Mackie and Rose (1991), Nohlen (1993), Singh and Bose (1986), and Wightman (1990).

17. Our data on ethnic groups (and on language groups, which we discuss at the end of the results section) come from the ClA World Factbook (1990, 1994), the Encyclopedia Britannica (1980), Vanhanen (1990), and the Worldmark Encyclopedia of the Nations (1984). We thank Olga Shvetsova for sharing her data with us.

18. Because the translation of legislative votes into legislative seats is not affected by whether presidential elections occur in the system, nor by the number and character of social cleavages, these variables should not affect ENPS once ENPV is included. We have verified that they do not. We also note that a model that excludes the intercept term works slightly less well than the model with the intercept, in terms of the root mean squared error ( .47 versus $.40)$.

19. These cases did not need to be omitted in the first regressions because, once the votes are given, the translation to seats is via the legislative electoral system--so the variables LML and UPPER retain their meaning. Omitting these cases does not in any event change any of our previous results.

20. We have also replaced the variable PROXIMITY*ENPRES with PROXIMITY*RUNOFF, to produce specifications along the lines of those offered by Mainwaring and Shugart (1995). This produces qualitatively similar results with poorer fits (adjusted $\mathrm{R}^{2 \text { ' }}$ around .3 ). As might be expected from the results in Table 3, if one pursues this more purely institutionalist specification, then a new electoral structure/social structure interatction term-RUNOFF*ENETH--is significant. In our formulation, this interaction is still significant but contributes only indirectly to the determination of ENPV, via its influence on ENPRES.

${ }^{21}$.. We view the effective number of ethnic groups as a crude proxy for social diversity sensu lato. Thus, we do not necessarily expect that more ethnic groups should lead to more ethnically-based parties. To begin to get predictions of this kind, one would have to take on the issue of cross-cutting cleavages in some fashion--which seems a hard task.

22. The interested reader can investigate this matter for him- or herself by fishing the dataset for this study off the web site noted in footnote 9. 
23. Or, to take account of the results with the minimun of LML and ENETH just mentioned, perhaps we should say that the effective number of parties depends on an interaction berween electoral and social structure. 